\title{
JOURNAL OF THE AMERICAN WATER RESOURCES ASSOCIATION
}

Vol. 43 , No. 1

AMERICAN WATER RESOURCES ASSOCIATION

February 2007

\section{THE CONTRIBUTION OF HEADWATER STREAMS TO BIODIVERSITY IN RIVER NETWORKS ${ }^{1}$}

\author{
Judy L. Meyer, David L. Strayer, J. Bruce Wallace, Sue L. Eggert, Gene S. Helfman, and Norman E. Leonard ${ }^{2}$
}

\begin{abstract}
The diversity of life in headwater streams (intermittent, first and second order) contributes to the biodiversity of a river system and its riparian network. Small streams differ widely in physical, chemical, and biotic attributes, thus providing habitats for a range of unique species. Headwater species include permanent residents as well as migrants that travel to headwaters at particular seasons or life stages. Movement by migrants links headwaters with downstream and terrestrial ecosystems, as do exports such as emerging and drifting insects. We review the diversity of taxa dependent on headwaters. Exemplifying this diversity are three unmapped headwaters that support over 290 taxa. Even intermittent streams may support rich and distinctive biological communities, in part because of the predictability of dry periods. The influence of headwaters on downstream systems emerges from their attributes that meet unique habitat requirements of residents and migrants by: offering a refuge from temperature and flow extremes, competitors, predators, and introduced species; serving as a source of colonists; providing spawning sites and rearing areas; being a rich source of food; and creating migration corridors throughout the landscape. Degradation and loss of headwaters and their connectivity to ecosystems downstream threaten the biological integrity of entire river networks.
\end{abstract}

(KEY TERMS: biotic integrity; intermittent; first-order streams; small streams; invertebrates; fish.)

Meyer, Judy L., David L. Strayer, J. Bruce Wallace, Sue L. Eggert, Gene S. Helfman, and Norman E. Leonard, 2007. The Contribution of Headwater Streams to Biodiversity in River Networks. Journal of the American Water Resources Association (JAWRA) 43(1):86-103. DOI: 10.1111/j.1752-1688.2007.00008.x

\section{INTRODUCTION}

Headwaters (i.e., springs and intermittent, firstand second-order streams) are abundant and unique components of a river network. They are found throughout the network, flowing into other first-order streams or into ones that are much larger. Small streams and springs occur across the range of climatic, geologic, riparian, and biogeographic settings of the United States This diversity produces differences in temperature, light, and hydrologic regimes, water chemistry, substrate type, food resources, and species pools, all of which affect the abundance and diversity of the biota. Because their catchments are not large and are easily influenced by small-scale differences in local conditions, headwater streams are arguably the most varied of all running-water habitats. They offer an enormous array of habitats for microbial, plant, and animal life, but their small size

\footnotetext{
${ }^{1}$ Paper No. J06014 of the Journal of the American Water Resources Association (JAWRA). Received February 3, 2006; accepted July 18, 2006. (c) 2007 American Water Resources Association.

${ }^{2}$ Respectively, Professor Emeritus, Institute of Ecology, University of Georgia, Athens, Georgia; Aquatic Ecologist, Institute of Ecosystem Studies, Millbrook, New York; Professor Emeritus, Department of Entomology and Institute of Ecology, University of Georgia, Athens, Georgia; Post-doctoral Associate, Department of Entomology, University of Georgia, Athens, Georgia; Professor, Institute of Ecology, University of Georgia, Athens, Georgia; and Ph.D. Candidate, Department of Biological Sciences, University of New Orleans, New Orleans, Louisiana (E-Mail/Meyer: jlmeyer@uga.edu).
} 
also makes them especially sensitive to disruption. Despite their abundance on the landscape and importance as habitat and as the origin of water resources, they are ignored in commonly used cartographic depictions. Small streams are neither named nor adequately indicated on standard topographic maps (1:24,000, USGS 7.5 min quads) (Meyer and Wallace, 2001).

The biota of headwater streams can be placed in five broad groups: (1) species that are unique to these small ecosystems; (2) species that are found in these and larger streams, although their abundance may vary with stream size; (3) species that move into headwaters seasonally as the stream network expands and contracts or as downstream conditions grow less favorable; (4) species that spend most of their lives in downstream ecosystems, but require headwaters at particular lifehistory stages (e.g., for spawning or nursery areas); and (5) species that live around but not in headwater streams, requiring the moist habitat they provide or feeding on the products of headwaters (e.g., benthic, emerging or drifting insects).

Headwaters are important for all of these groups and therefore are integral to the maintenance of biological diversity in the river network. In the following sections, we (1) provide an overview of the diversity of organisms that depend on small streams, (2) discuss the ecological factors that make these habitats favorable for so many species, (3) illustrate the ecological connectivity that exists between headwater and downstream ecosystems, and (4) discuss the ways in which downstream biota depend upon headwater ecosystems.

\section{BIOLOGICAL DIVERSITY IN SMALL STREAMS}

\section{Primary Producers}

The algal communities of headwaters are dominated by diatoms (e.g., Cymbella, Gomphoneis, Fragilaria), cyanobacteria (e.g., Schizothrix, Phormidium), red algae (e.g., Batrachospermum), and green algae (e.g., Stigeoclonium) (Biggs, 1996). In systems where the headwaters are shaded and low in nutrients, 30-60 algal species are commonly encountered, some of which are not found elsewhere in the river network (Rex Lowe, personal communication). For example, the algal community of a rivulet flowing from an Ontario spring consisted of 34 taxa, 32 of which were diatoms (Sherwood et al., 2000). Although algal taxa richness increased downstream, eight of the taxa found in the first $20 \mathrm{~m}$ of the stream were not found at stations further downstream (Sherwood et al., 2000). Rocks and bryophytes in a shaded headwater stream in the southern Appalachians supported 40 algal taxa, 30 of which were diatoms (Greenwood, 2004; Greenwood and Rosemond, 2005). Only a few taxa were abundant; two taxa each represented $>20 \%$ of the biovolume, whereas each of 29 other taxa represented $<1 \%$ (Greenwood and Rosemond, 2005). Recent research in continuously flowing Alaskan springs has revealed a diverse algal assemblage that serves as a source of propagules for the downstream flora once those larger streams begin to thaw (Huryn et al., 2005).

Bryophytes (mosses and liverworts) commonly dominate the biomass of primary producers in small streams. Mosses can use only carbon dioxide in photosynthesis and are most diverse and abundant in headwater streams and seeps where water is rich in carbon dioxide (Stream Bryophyte Group, 1999). Bryophyte species richness ranged from 0 to 14 species in small boreal streams (Heino et al., 2005). Four species dominate the bryophyte flora of small, high-gradient Appalachian streams; Fontinalis dalecarlica and Hygroamblystegietum fluviatile are most abundant in first through third-order streams (Glime, 1968). Mosses and liverworts attach to hard substrates and provide habitat that supports many invertebrate species (Stream Bryophyte Group, 1999).

The types of primary producers found in headwater streams vary greatly as a function of light and hydrologic regime. In well-lit, hydrologically stable springs, a diversity of vascular plants can be found including species endemic to springs such as Zizania texana (Texas wild rice) (Hubbs, 1995). A survey of macrophyte diversity in 79 small (mean width $1.9 \mathrm{~m}$ ), unshaded, lowland streams found 11-24 species per stream (mean $=18.5$ species $)$ and a total of 131 species (Baattrup-Pedersen et al., 2003). The headwaters of the Upper Mississippi River flow through bogs and swamps with high vascular plant diversity (Delong, 2005). In headwater streams flowing through steeper and forested catchments, angiosperm diversity is often low and increases as stream width increases. For example, the first $20 \mathrm{~m}$ of an Ontario spring-fed stream housed only three vascular plant species, whereas 9-14 species occurred at sites further downstream (Sherwood et al., 2000). In addition to being primary producers in small streams, vascular plants can act as sieves, trapping particles of organic matter (Horvath, 2004). This increases the organic matter availability to consumers in the headwaters, but decreases organic matter transport downstream.

\section{Decomposers}

From a taxonomic perspective, bacteria are the least known organisms in headwater streams; however, 
we know much about their functional role in stream biogeochemical cycles and food webs (e.g., Hall and Meyer, 1998). They are critical to processing of organic matter, which alters nutrient and organic matter exports from small streams to downstream ecosystems as described elsewhere in this series of papers (Wipfli et al., this issue). Dissolved organic carbon (DOC) provides the $\mathrm{C}$ source supporting bacterial metabolism and is the most abundant form of organic matter exported from headwaters to downstream ecosystems (Allan, 1995). Leaching of leaf litter is one source of DOC in headwaters that generates a diversity of compounds that differ in their availability to bacteria. Highly labile DOC supports local bacterial metabolism, whereas DOC of intermediate lability is exported and supports bacterial metabolism downstream (Wiegner et al., 2005). Bacteria from headwater sites were able to grow on DOC leached from a nearby riparian species, whereas bacteria collected further downstream were able to use DOC leached from a wider array of species (Koetsier et al., 1997). Genetic diversity of bacteria did not vary significantly with distance downstream in a blackwater stream (McArthur et al., 1992). However, genetic similarity between sites decreased with increasing distance downstream, suggesting genetic differences among headwater and downstream populations of a species (McArthur et al., 1992). Methods for assessing bacterial diversity are recent and still developing, and have not been applied to the entire bacterial assemblages in headwater streams. On the basis of what has been discovered in soils (Tiedje et al., 1999), we would expect the sediments and biofilm of headwater streams to contain at least hundreds to thousands of types of bacteria.

Fungi are also crucial to organic matter dynamics and food webs in headwater streams, and we know considerably more about their diversity than about bacterial diversity. Fungi in headwater streams are primarily hyphomycetes, ascomycetes, and oomycetes. Species composition changes markedly along the course of a stream (Tsui et al., 2001), but is high even in very small streams (Suberkropp and Wallace, 1992; Gulis and Suberkropp, 2004). Over 51 taxa of aquatic hyphomycete fungi have been found in two tiny streams in the southern Appalachians, where inputs of leaf litter from the surrounding forest are high (Gulis and Suberkropp, 2004). When leaf litter inputs to a headwater stream were experimentally eliminated, fungal taxa richness declined from 43 to 36 taxa (Gulis and Suberkropp, 2003). Fungal species composition and richness in headwater streams are strongly influenced by the species composition of riparian vegetation and water chemistry (Bärlocher and Graca, 2002; Gulis and Suberkropp, 2004).

\section{Insects}

As water first emerges from the ground in a spring or seep, it provides habitat for an array of insect species. Thirteen species of caddisfly were found within $20 \mathrm{~m}$ of the source of an Appalachian springbrook (McCabe and Sykora, 2000). As many as 18 caddisfly species were found in individual California springs (Erman and Erman, 1995), and from 5 to 38 chironomid taxa were identified from individual springs in the High Plains (Blackwood et al., 1995). Unique faunal assemblages have been linked to characteristic water chemistries of springs, reflecting different levels of contamination of their ground-water sources (Williams et al., 1997).

The springs and small seeps that provide habitats at the beginnings of a river network are inadequately mapped. A study in headwater streams of West Virginia and Kentucky illustrates this point. From February through April 2000, Stout and Wallace (2003) sampled from the first continuous flowing water downstream to either a confluence or the point on a topographic map where a solid blue line stream began; i.e., they sampled 34 flowing streams that were unmapped or indicated as intermittent. Their samples included over 86 insect genera in 47 families. Ephemeroptera, Plecoptera, and Trichoptera (EPT) taxa richness, commonly used as an indicator of water quality, increased with distance from the source in these unnamed streams (Figure 1). The seeps where water first emerged from the ground had

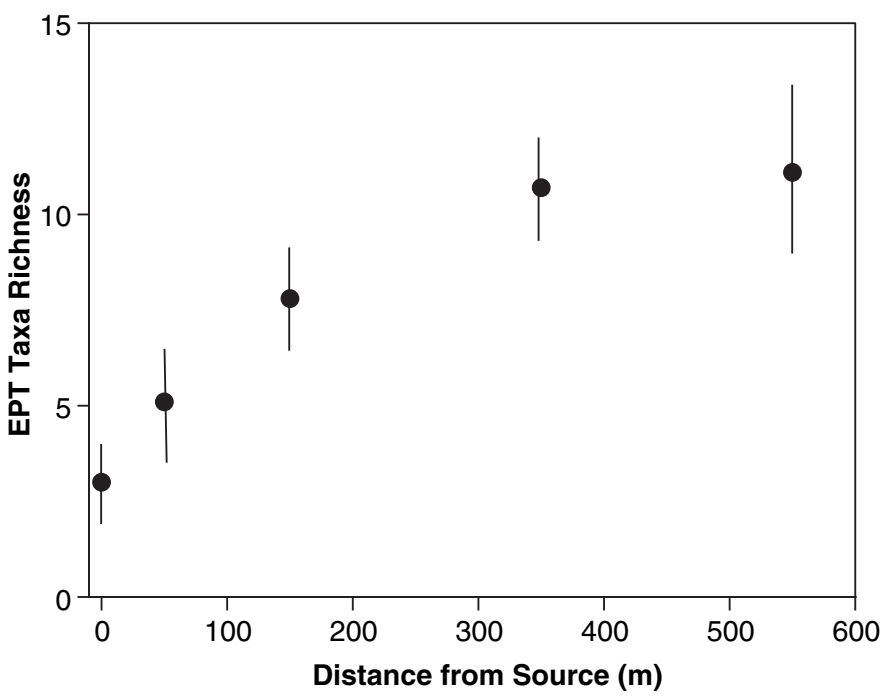

FIGURE 1. Taxa Richness (Mean $\pm 95 \%$ CI) for Insects in the Orders Ephemeroptera, Plecoptera, and Trichoptera Collected From 34 Unmapped Headwater Streams in Kentucky and West Virginia. Richness is plotted vs. distance from the point at which water emerged from the ground. Data are from Stout and Wallace (2003). 
an average of three EPT taxa; sites within only $150 \mathrm{~m}$ of the source had an average of eight EPT taxa; and EPT taxa richness was similar (11 taxa) at 350 and $500 \mathrm{~m}$ from the source. Although these streams were either unmapped or designated as intermittent, EPT and other insect taxa with multiyear aquatic life cycles were found in these streams, some with catchments as small as 4 ha (Stout and Wallace, 2003).

Long-term stream research at Coweeta Hydrologic Laboratory in North Carolina provides further evidence of the diversity of aquatic insects in very small, unmapped streams (Table 1). At least 51 families and 145 genera of aquatic insects have been collected over three decades of sampling in eight headwater streams with catchments ranging in size from 5 to 61 ha. None of these streams is shown on standard topographic maps. Putting this taxonomic diversity into some perspective, there are only 33 families and 80 genera of freshwater fishes in the entire state of North Carolina (Menhinick, 1991).

TABLE 1. Diversity in Aquatic Insects Found in Headwater Streams of Coweeta Hydrologic Laboratory in the Southern Appalachian Mountains of Western North Carolina (Courtney, 1994, 2000; Gurtz, 1981; Huryn, 1990; Huryn and Wallace, 1985, 1987a,b, 1988; Lugthart and Wallace, 1992; Wallace et al., 1991, 1999).

\begin{tabular}{lcc}
\hline Order & $\begin{array}{c}\text { Number of } \\
\text { Families }\end{array}$ & $\begin{array}{c}\text { Number of } \\
\text { Genera }\end{array}$ \\
\hline Ephemeroptera (mayflies) & 5 & 10 \\
Odonata (dragonflies, & 2 & 2 \\
damselflies) & 8 & 15 \\
Plecoptera (stoneflies) & 1 & 1 \\
Megaloptera (alderflies, & 3 & 4 \\
dobsonflies) & 13 & 22 \\
Coleoptera (beetles) & 19 & $91^{*}$ \\
Trichoptera (caddisflies) & 51 & 145 \\
Diptera (true flies) & & \\
Total & & \\
\hline
\end{tabular}

*Includes Chironomidae.

Small streams contain unique as well as widely distributed insect species. A list of eastern North American stoneflies that occur only in first- and second-order streams includes 60 species in 24 genera and 8 families (R.F. Kirchner and B.C. Kondratieff in Stout and Wallace, 2003). Thirty-six of the 78 caddisfly species in a Sierra Nevada stream network were found only in springs; eight of these were restricted to constant temperature springs (Erman and Erman, 1995). Species composition differed greatly among individual streams; on average, only $23 \%$ of species were similar among streams (Erman and Erman, 1995). Insect samples from seven central Oregon springs and seeps included 106 species; $92 \%$ of those were found only in the springs and seeps and not in the main creek (Anderson and Anderson, 1995). Most of the uniquely spring species were dipterans.

Aquatic insect diversity is high in the southeastern United States; $40 \%$ of the North American aquatic insect fauna can be found in the Southeast (Morse et al., 1997). Much of this richness is in small springs and streams (Morse et al., 1997). For example, extensive sampling in a Louisiana spring complex captured 43 caddisfly species including 5 endemics (Morse and Barr, 1990). Over 650 insect species have been found in Upper Three Runs Creek, a fourth-order stream on South Carolina's Coastal Plain; 180 species are found in its second-order tributaries, and many are found only in the headwaters (Morse et al., 1980, 1983; John Morse personal communication). The spring-fed ravine ecosystems of northern Florida harbor 138 caddisfly and 23 stonefly species, which represent $70 \%$ and 55\%, respectively, of all Florida species in these orders (Rasmussen, 2004). The high-gradient streams of the Appalachians are also rich in insect species, with collector-gatherers and shredders as the largest contributors to secondary production in the headwaters (Wallace et al., 1992).

Even small streams that do not flow continuously may contain a rich and sometimes unique insect fauna. An intensive study of seven "summer-dry" (i.e., intermittent) streams in western Oregon < $12 \mathrm{~km}$ apart found 202 aquatic or semi-aquatic insect species, at least 13 of which were new to science (Dieterich and Anderson, 2000). The two intermittent streams that were in forest settings had more insect species (125-126 species) than a permanent headwater stream (100 species) in the same setting. Considering the entire species pool, $8 \%$ were found only in permanent headwaters, $25 \%$ were restricted to intermittent streams, and $67 \%$ were found in both. Over half of the species found were dipterans, and EPT taxa comprised about $30 \%$ of the insect fauna (Dieterich and Anderson, 2000). Somewhat higher taxonomic richness was observed in permanently flowing streams (71-92 taxa) than in intermittent streams (54-93 taxa) in another group of western Oregon streams, although the peak emergence biomass was three times higher in the intermittent streams (Progar and Moldenke, 2002). This emerging biomass provides a food resource for riparian consumers. In these streams, only two EPT genera were unique to the intermittent channels, and most taxa were common to both stream types. In the southeastern United States, 171 taxa were found in six small Alabama streams that varied in their permanence (Feminella, 1996). Only 7\% of taxa were found exclusively in intermittent streams, whereas $75 \%$ of taxa were found in both perennial and intermittent streams. In the Southwestern United States, 10 species of winter-emerging stoneflies were found in New 
Mexico streams that are dry for long periods in spring and autumn (Jacobi and Cary, 1996). Adaptations for life under these conditions include small size, rapid development, and a period of diapause during egg or larval stages. Subarctic Alaskan streams do not flow in winter because they are frozen. Although some dipteran species have adaptations that allow them to survive freezing, most aquatic invertebrates die when streambeds freeze; these species survive by migrating away from a freezing front or remaining in habitats such as headwater springs that do not freeze (Irons et al., 1993; Huryn et al., 2005). These refugia serve as sources of colonists when streams begin to thaw (Huryn et al., 2005).

\section{Mollusks, Crustaceans, and Other Invertebrates}

The invertebrate fauna of hardwater springs is dominated by crustaceans, triclads, and mollusks (Glazier, 1991). Although mollusk diversity is generally the greatest in larger rivers, mollusks can also be conspicuous and abundant in headwaters. Many species are headwater specialists with small geographic ranges. For example, members of the prosobranch family Hydrobiidae frequent springs and spring-fed streams throughout the USA. About 200 rare headwater hydrobiid species occur in the USA. (listed by NatureServe 2005 as imperiled or critically imperiled [G2 or G1]), with dozens of narrowly endemic species from the Southeast, the Great Basin and the Northwest (Herschler, 1994; Frest and Johannes, 1999). Nineteen headwater species are either protected by the Endangered Species Act or are rare enough to be considered for listing. Hydrobiids, physids, and lymnaeids are the most abundant mollusks in hardwater springs in the temperate zone (Glazier, 1991). The pleurocerid snails such as Goniobasis and Juga are often dominant grazers in headwaters of the Southeast and Northwest (Lamberti, 1996; Steinman, 1996). Their absence from intermittent streams has been suggested as one of the factors responsible for high diversity of insect grazers in those systems (Dieterich and Anderson, 2000). Pearl mussels (Margaritifera spp.) can also be extremely abundant $\left(>100 \mathrm{~m}^{-2}\right)$ in small streams (Johnson and Brown, 2000).

Crustaceans such as amphipods, isopods and crayfish are conspicuously abundant in headwaters. Microcrustaceans such as cladocerans, ostracods, and copepods also live in headwaters, where they can reach very high densities $\left(>10,000 \mathrm{~m}^{-2}\right.$, Galassi et al., 2002). Although fewer than 10 species of macrocrustaceans inhabit a typical headwater site, species composition varies greatly across headwaters; North
America supports 600-700 species of large freshwater crustaceans, many of them in headwater streams. The NatureServe database lists 31 amphipod, 4 isopod, and 11 crayfish species as found in springs and springbrooks; of these, 30 amphipod, 3 isopod, and 5 crayfish species are considered imperiled or critically imperiled (G1 or G2, Larry Master, personal communication). Amphipods and isopods are most common in relatively constant, cool waters, where they can reach high densities (Covich and Thorp, 1991). The southeastern United States has the highest number of crayfish species (Taylor et al., 1996). Crayfish comprise a large portion of the biomass in many headwater streams; e.g., they comprise $>90 \%$ of macroinvertebrate biomass in perennial headwaters of coastal Washington (Haggerty et al., 2002). Macrocrustaceans are not confined to perennial streams. In fact, total crayfish densities were higher in intermittent than in perennial streams in the south-central United States; two species (Orconectes puntimanus and $O$. marchandi) had significantly greater numbers in intermittent streams, whereas abundance of the other two species did not differ with stream type (Flinders and Magoulick, 2003).

Small streams support many invertebrate taxa other than insects, mollusks and crustaceans (Table 2), although they have not been as extensively studied. A typical headwater stream might contain $30-300$ species and $20,000-2,000,000 \mathrm{~m}^{-2}$ of these other taxa, such as turbellarians, gastrotrichs, and nematodes (Table 2). Species richness in these groups may be as high in headwaters as in larger streams (e.g., Kolasa, 1983), and many can be found in intermittent streams. Many are unique to headwaters; e.g., most of the endemic lumbriculid oligochaetes recently discovered in the Pacific Northwest live in seeps, springs, and small streams (McKey-Fender and Fender, 1988; Fend and Brinkhurst, 2000; Fend and Gustafson, 2001).

\section{Fishes}

Stream fish diversity generally increases with increasing stream size along a gradient of increasing habitat heterogeneity, pool development, and habitat volume (Schlosser, 1987). The extent to which species richness changes with stream size varies considerably. From 3 to 11 species were found in a secondorder Kentucky stream vs. 12-25 in a fourth-order stream (Kuehne, 1962); a Texas headwater stream contained 22 species, whereas downstream sections had 33 species (Evans and Noble, 1979). In some cases, the increase in fish species with increasing stream size occurs as a result of species additions, so that headwater assemblages represent a nested 
The Contribution of Headwater Streams to Biodiversity in River Networks

TABLE 2. Invertebrates Other Than Mollusks, Crustaceans, and Insects That Are Common in Headwaters.

\begin{tabular}{|c|c|c|c|}
\hline Group & $\begin{array}{c}\text { Typical Species } \\
\text { Richness in } \\
\text { Headwaters }\end{array}$ & $\begin{array}{c}\text { Typical Density } \\
\text { in Headwaters } \\
\left(\text { no. } / \mathbf{m}^{2}\right)\end{array}$ & Key References \\
\hline Turbellaria & $3-30$ & $1,000-10,000$ & Kolasa $(1983,2002)$ \\
\hline Gastrotricha & $3-30(?)$ & $10,000-300,000(?)$ & $\begin{array}{l}\text { Strayer and Hummon (2001), Balsamo } \\
\text { and Todaro (2002) }\end{array}$ \\
\hline Rotifera & $20-200$ & $10,000-1,000,000$ & $\begin{array}{l}\text { Schmid-Araya (1998), Wallace } \\
\text { and Ricci (2002) }\end{array}$ \\
\hline Nematoda & $10-100$ & $5,000-500,000$ & Traunsperger (2002) \\
\hline Tardigrada & $1-10$ & $1,000-10,000(?)$ & Nelson and McInnes (2002) \\
\hline Oligochaeta & $3-30$ & $1,000-50,000$ & Schwank $(1981 a, b)$ \\
\hline Acari & $5-50$ & $100-10,000$ & Di Sabatino et al. $(2002,2003)$ \\
\hline Total & $40-450$ & $28,000-1,880,000$ & \\
\hline
\end{tabular}

Question marks indicate substantial uncertainty in poorly studied groups.

subset of species found throughout the network (e.g., Taylor and Warren, 2001). In other cases, diversity increases but the species are different from those found in the headwaters. For example, small insectivorous fishes numerically dominate first- and secondorder streams in the southeastern Coastal Plain; the same species are rare in larger streams (Paller, 1994). Because headwater streams may contain a unique species assemblage, they can make a significant contribution to regional fish diversity (e.g., Paller, 1994).

The location of a small stream in the network also affects its richness (Matthews, 1998). The fish assemblages in second-order Texas streams flowing into other second order streams had a Shannon diversity index of 0.94 , whereas second-order streams flowing into third and fourth-order streams had diversity indices of 1.13 and 1.84, respectively (Whiteside and McNatt, 1972). The higher diversity in the streams that flow into larger streams is a consequence of species from the larger stream moving into the tributaries.

Small streams are characterized by small-bodied species such as small minnows, madtom catfishes, darters, and sculpins (Schlosser, 1987). For example, small-bodied insectivorous fishes are numerically dominant in first-order streams in Mississippi, with species richness ranging from 2 to 36 species (Smiley et al., 2005). Samples from only 14 first-order streams in managed pine forests included 18\% of Mississippi's native fish species (Smiley et al., 2005). The fish fauna in cold eastern and western North American headwater streams usually consists of a salmonid species, a sculpin, and 1-3 species of cyprinids or catastomids (Moyle and Herbold, 1987). In high-gradient Southern Appalachian streams brook trout (Salvelinus fontinalis) are found furthest upstream, with sculpin (e.g., Cottus bairdi), dace (e.g., Rhinichthys atratulus), and darters (e.g., Etheostoma flabellare) slightly further downstream (Wallace et al., 1992).
Throughout the southeastern United States, darters in the genera Etheostoma and Percina contribute to fish diversity in headwaters with 73 species whose habitat descriptions in the NatureServe database include the terms springs, small streams, headwaters, or small creeks. That database lists 180 fish species whose distributions include springs and springbrooks (L. Master, personal communication).

Springs and spring runs often contain unique fish faunas, including endemics found in only one or two springs (Hubbs, 1995). The NatureServe database identifies 49 fish species as exclusive to springs and springbrooks; 30 of these species are ranked as critically imperiled, imperiled, or extinct (NatureServe ranks of G1, G2, or GX; L. Master, personal communication). Many extirpated and threatened southwestern fishes are spring inhabitants. For example, 13 species of pupfishes (Cyprinodon spp.) are found in springs in the southwestern United States, 12 of which have NatureServe ranks of G1, G2, or GX. Six endemic Gambusia species occur in stenothermal Texas springs, and those species are replaced by the widespread mosquitofish Gambusia affinis in downstream reaches (Hubbs, 1995). Unique spring species are also found in more mesic regions. For example, Etheostoma nuchale is a darter endemic to two springs in Alabama (Hubbs, 1995); the coldwater darter, $E$. ditrema, has a similar limited distribution.

Fish also occur in intermittent stream habitats. Ten intermittent tributaries of a river in Colorado contained 11 native fish species. Five of those species penetrated $7-9 \mathrm{~km}$ upstream in tributaries that were dry except for isolated pools, which were maintained by an extensive ground-water aquifer (Fausch and Bramblett, 1991). Rogue River tributaries that were dry in summer supported large spawning populations of steelhead salmon (Oncorhynchus mykiss) in winter (Everest, 1973 in Erman and Hawthorne, 1976). A striking $39-47 \%$ of adult rainbow trout (O. mykiss) in Sagehen Creek, California, spawned in one 
intermittent tributary and only $10-15 \%$ spawned in the perennial main channel (Erman and Hawthorne, 1976). Intermittent streams and ephemeral swamps contributed $15 \%$ and $23 \%$ of coho salmon (Oncorhynchus kisutch) smolts, respectively, during 2 years in the $10 \mathrm{~km}^{2}$ Carnation Creek catchment (Brown and Hartman, 1988). The proportion of smolts from intermittent tributaries was higher during 1 year because extensive flows washed out smolts in the main channel and lower during the other year because low spring flows decreased the connectivity between the main stem and intermittent habitats. A recent study in coastal Oregon streams found $11-21 \%$ of adult coho salmon populations spawning in intermittent streams (Wigington et al., 2006). Furthermore, juvenile coho tagged in the main channel entered intermittent tributaries during high autumn flows, and smolts that used intermittent tributaries were larger than those using permanent tributaries (Wigington et al., in review).

Many fish species that spend most of their lives in larger streams, rivers, or lakes use small streams for spawning and nursery areas. In addition to the coho salmon, steelhead, and rainbow trout just described, cutthroat trout (Oncorhynchus clarki) and chum salmon (Oncorhynchus keta) migrate into very small tributary streams to spawn, navigating riffles with half of their bodies out of the water. During their first summer of life, $81 \%$ of brook trout spawned in a Canadian lake moved into tiny tributary streams to take advantage of favorable flows and temperatures (Curry et al., 1997). Fishes other than salmonids also use small tributaries for spawning and nursery areas. For example, the trispot darter (Etheostoma trisella) is an imperiled southeastern species that lives along the edge of a small river but spawns in a seepage stream ( $<1 \mathrm{~m}$ wide) flowing through a marshy pasture (Ryon, 1986); the slackwater darter, Etheostoma boschungi, spawns in similar habitats.

Hence, we can identify three broad classes of fishes that use headwater streams and springs. Headwater specialists use small streams throughout the year. This group includes species of minnows (Phoxinus, Rhinichthys, Hemitremia), pupfish (Cyprinodon), topminnows (Fundulus), sculpins (Cottus), and darters (Etheostoma and Percina). A second class includes generalists that use headwaters as one of many habitats. Many trout, minnows such as creek chub, madtom catfish (Noturus), and small sunfishes (e.g., pygmy sunfishes, Elassoma) are in this group. These species may maintain permanent populations in headwaters or move into and out of them as the stream network expands and contracts. Some can be found in water barely deep enough for them to swim, such as the pygmy sunfishes that occur in inflow regions of southeastern swamps. The third group lives in larger systems but uses small streams for spawning and nursery areas as described above.

Headwater fish species are vulnerable to extirpation. In the southeastern United States $25 \%$ of the 16 headwater species and $70 \%$ of the 10 spring species are considered to be jeopardized (Table 3 and Etnier, 1997). Small-bodied fishes that spawn, feed or seek shelter on the stream bottom are particularly vulnerable (Burkhead et al., 1997; Burkhead and Jelks, 2000). Highland endemic species, many that occupy headwater habitats, are being replaced by more cosmopolitan species as southern Appalachian streams are degraded (Scott and Helfman, 2001). Threats to headwater fishes are not unique to the southeastern United States. Headwater species account for $29 \%$ of

TABLE 3. Southeastern Fish Species Whose Preferred Habitat Is Headwaters or Springs According to Etnier (1997).

Headwater Species

Notropis chrosomus (rainbow shiner)

N. signipinnis (flagfin shiner)

Phoxinus cumberlandensis (blackside dace)*

$P$. erythrogaster (southern redbelly dace)

$P$. tennesseensis (Tennessee dace)*

$P$. sp.cf. erythrogaster *

Rhinichthys atratulus (blacknose dace)

Semotilus atromaculatus (creek chub)

S. lumbee (sandhills chub)*

$S$. thoreauianus (Dixie chub)

Catostomus commersoni (white sucker)

Salvelinus fontinalis (brook trout)

Etheostoma parvipinne (goldstripe darter)

E. sagitta (arrow darter)

E. spectabile (orangethroat darter)

E. whipplei (redfin darter)
Spring Species

*Indicates species that Etnier (1997) identified as jeopardized or extinct. This list does not include species that use headwaters for breeding. 
all fish species in the Maumee (98 total species) and Illinois (135 species) rivers, and headwater specialists have been particularly vulnerable to extirpation (Karr et al., 1985). From 50\% to $64 \%$ of headwater species are either declining or extirpated from those rivers (Karr et al., 1985). A tabulation of headwater and spring fish species that are presumed Extinct or listed as Threatened, Endangered, or Candidate species under the Endangered Species Act includes at least 13 species dependent on small or intermittent streams and 23 spring-dwelling species (Table 4). This is an extremely conservative estimate; many more headwater- and spring-dwelling fishes are recognized as imperiled by the American Fisheries Society (Warren et al., 2000).

In contrast to this pattern of threatened species in headwaters, protected headwater streams can serve as a refuge for species extirpated from other parts of the network. For example, the smallest known parasitic lamprey species (Lampetra minima) was thought to be extinct after the endemic population in Miller Lake was eliminated via poisoning in 1958. Later collections in small tributaries revealed previously unknown populations of the species (Lorion et al., 2000).

\section{Amphibians and Reptiles}

Stream-dwelling amphibians can be found in streams as both larvae and adults (Petranka, 1998). Many spend their entire life history within streams, whereas others use streams while larvae, venture into terrestrial habitats as adults, and return to streams only to reproduce. In Appalachian streams, amphibians are primarily found in habitats that lack fish, but the Dicamptodon of the western United States and Necturus of the Southeast share their habitats with fishes. The tadpoles of some Rana and Bufo also survive where fishes are present.

Salamanders (larvae and adults) and frogs (adults) can be the dominant vertebrate predators in systems where they occur (Burton and Likens, 1975; Werner and McCune, 1979), and tadpoles exert significant grazing pressure on algae (Stebbins and Cohen, 1995). The presence of amphibians in headwater streams increases the biodiversity by acting as keystone predators (e.g., Fauth and Resetarits, 1991).

North American amphibian databases list 84 salamander species in 18 genera whose habitats include small streams, seeps, springs, or headwater streams (Table 5). In high-gradient Appalachian streams, 3-5

TABLE 4. Fish Species Associated with Small Streams and Springs That Are Presumed Extinct (*) or Are Listed as Threatened, Endangered, or Candidate Species under the Endangered Species Act.

\begin{tabular}{|c|c|}
\hline Small Stream Species & Spring Species \\
\hline $\begin{array}{l}\text { Phoxinus cumberlandensis (blackside dace) } \\
\text { Catostomus santaanae (Santa Ana sucker) } \\
\text { Oncorhynchus clarkii seleniris (Paiute cutthroat trout) } \\
\text { O. mykiss pop. } 10 \text { (steelhead - southern California) } \\
\text { O. mykiss whitei (Little Kern golden trout) } \\
\text { Gasterosteus aculeatus williamsoni } \\
\text { (unarmored threespine stickleback) } \\
\text { Etheostoma chienense (relict darter) } \\
\text { E. cragini (Arkansas darter) } \\
\text { E. fonticola (fountain darter) } \\
\text { E. okaloosae (Okaloosa darter) } \\
\text { E. phytophilum (rush darter) } \\
\text { E. scotti (Cherokee darter) } \\
\text { E. susanae (Cumberland Johnny darter) }\end{array}$ & $\begin{array}{l}\text { Eremichthys acros (desert dace) } \\
\text { Gila intermedia (Gila chub) } \\
\text { Lepidomeda albivallis (White River spinedace) } \\
\text { L. altivelis * (Pahranagat spinedace) } \\
\text { Rhinichthys osculus nevadensis \& other subspp. } \\
\text { (Ash Meadows speckled dace) } \\
\text { Fundulus albolineatus* (whiteline topminnow) } \\
\text { Gambusia gaigei (Big Bend gambusia) } \\
\text { G. georgei (San Marcos gambusia) } \\
\text { G. heterochir (Clear Creek gambusia) } \\
\text { G. nobilis (Pecos gambusia) } \\
\text { Cottus paulus (pygmy sculpin) } \\
\text { Crenichthys baileyi (White River springfish) } \\
\text { C. nevadae (Railroad Valley springfish) } \\
\text { Cyprinodon arcuatus * (Santa Cruz pupfish) } \\
\text { C. bovines (Leon Springs pupfish) } \\
\text { C. diabolis (Devil's Hole pupfish) } \\
\text { C. elegans (Comanche Springs pupfish) } \\
\text { C. macularius (desert pupfish) } \\
\text { C. nevadensis (Amargosa pupfish) } \\
\text { (2 subspp. extinct) } \\
\text { C. radiosus (Owens River pupfish) } \\
\text { Empetrichthys latos (Pahrump poolfish) } \\
\text { E. merriami* (Ash Meadows poolfish) } \\
\text { Etheostoma nuchale (watercress darter) }\end{array}$ \\
\hline
\end{tabular}

Note: This is a very conservative listing of species considered imperiled by experts; e.g., of the 11 species identified as jeopardized by Etnier (1997) (see Table 3), only four are listed here, and one of those is extinct. 
TABLE 5. Reptile and Amphibian Genera with Species Whose Habitats Include Small Streams, Seeps, Springs, or Headwater Streams.

\begin{tabular}{|c|c|c|}
\hline & Genus & No. of Species \\
\hline \multirow[t]{18}{*}{ Salamanders } & Ambystoma & 6 \\
\hline & Amphiuma & 3 \\
\hline & Dicamptodon & 4 \\
\hline & Desmognathus & 17 \\
\hline & Eurycea & 25 \\
\hline & Gyrinophilus & 4 \\
\hline & Haideotriton & 1 \\
\hline & Hemidactylium & 1 \\
\hline & Hydromantes & 3 \\
\hline & Necturus & 5 \\
\hline & Phaeognathus & 1 \\
\hline & Plethodon & 2 \\
\hline & Pseudotriton & 2 \\
\hline & Rhyacotriton & 4 \\
\hline & Pseudobranchus & 2 \\
\hline & Siren & 2 \\
\hline & Stereochilus & 1 \\
\hline & Typhlotriton & 1 \\
\hline \multirow[t]{7}{*}{ Frogs } & Acris & 2 \\
\hline & Ascaphus & 2 \\
\hline & Hyla & 2 \\
\hline & Pseudacris & 2 \\
\hline & Rana & 18 \\
\hline & Smilisca & 1 \\
\hline & Xenopus* & 1 \\
\hline \multirow[t]{2}{*}{ Toads } & Spea & 2 \\
\hline & Bufo & 6 \\
\hline \multirow[t]{4}{*}{ Turtles } & Chelydra & 1 \\
\hline & Kinosternon & 6 \\
\hline & Sternotherus & 4 \\
\hline & Apalone & 3 \\
\hline \multirow[t]{5}{*}{ Snakes } & Nerodia & 7 \\
\hline & Regina & 4 \\
\hline & Seminatrix & 1 \\
\hline & Agkistrodon & 1 \\
\hline & Farancia & 2 \\
\hline
\end{tabular}

Note: Data are from NatureServe (accessed July and October 2005), AmphibiaWeb (http://www.amphibiaweb.org), Global Amphibian Assessment (http://www.globalamphibians.org), IUCN Red List (http://www.redlist.org), and Center for North American Herpetology (http://www.naherpetology.org, accessed October 2005).

*Introduced into North America.

species of salamanders in the genera Desmognathus, Eurycea, Gyrinophilus, and Leurognathus occur and are the dominant vertebrate predators in the smallest headwaters; their secondary production is higher in first-order streams than in third-order streams (Wallace et al., 1992). Salamander larvae feed almost exclusively on aquatic invertebrates (Johnson and Wallace, 2005). In the northeastern United States, stream amphibian diversity is concentrated in headwater streams (reports cited in Lowe and Bolger, 2002). Population size of the spring salamander, Gyrinophilus porphyriticus, was the highest in small streams without brook trout and lower where connectivity with downstream ecosystems was compromised (Lowe and Bolger, 2002).

Several frog and toad species also occur in small streams: 28 species of frogs in seven genera and eight species of toads in two genera occur in small streams and springs (Table 5). At least two of these species are considered rare (G1 or G2 in NatureServe, 2003), and one (Rana fisheri) is presumed extinct. Also listed is Xenopus laevis, a species native to Africa and introduced to novel habitats in North America; introductions of this exotic species may be responsible for the introduction of Chytrid fungi to the USA (Weldon et al., 2004). This is an example of a headwater species with an impact far beyond the headwaters.

Reptiles (chiefly turtles and snakes) may also be found in headwater habitats including intermittent streams (e.g., Stone, 2001). Fourteen species of turtles in 4 genera and 15 species of snakes in five genera are found associated with small streams (Table 5). Although reptiles are not usually restricted to or most abundant in these habitats (Buhlmann and Gibbons, 1997), species in several genera (e.g., Nerodia, Farancia, and Regina) specialize on aquatic prey items. The genera listed in Table 5 represent taxa with the strongest ties to headwater habitats and do not include several species that are only loosely associated with streams (e.g., certain species of Carolina, Elaphe, Thamnophis, and Nerodia).

\section{Birds and Mammals}

Only a few species of birds (e.g., dippers, Cinclus mexicanus) actually live in small streams, but many depend on headwaters for food, water, habitat, or movement corridors. The preferred habitat of Louisiana and northern water thrushes (Seiurus noveboracensis and $S$. motacilla) is small headwater streams (Prosser and Brooks, 1998). The Virginia rail (Rallus limicola) is listed as a species exclusive to springs and springbrooks in the NatureServe database (L. Master, personal communication). Many other species are attracted to the large hatches of aquatic insects that emerge from headwater streams. Birds like flycatchers can be especially abundant around streams (Murray and Stauffer, 1995), and overall bird abundance may be elevated near headwater streams (Wiebe and Martin, 1998). Bird species richness and evenness were higher in the riparian zone of the first and secondorder Michigan streams than in the uplands, and 12 species were found only in the riparian zone (Bub et al., 2004). Abundance of several bird species was closely correlated with aquatic insect emergence in small prairie streams (Gray, 1993). Birds such as herons and kingfishers feed on fish and aquatic invertebrates in pools of intermittent streams (e.g., Tramer, 1977). 
TABLE 6. A Minimum Estimate of Taxa Associated with Three Small, Shaded Streams (Average Discharge $<2.5 \mathrm{~L} / \mathrm{s}$ ) on Catchments 53, 54, 55 (5-7.5 ha) at Coweeta Hydrologic Laboratory, NC.

\begin{tabular}{|c|c|c|}
\hline Taxon & Estimated Number of Taxa & Reference \\
\hline Algae & $\begin{array}{l}30 \text { diatom species } \\
10 \text { other algal taxa }\end{array}$ & Greenwood (2004), Greenwood and Rosemond (2005) \\
\hline Bryophyta & 7 moss and 4 liverwort taxa & Greenwood (personal communication) \\
\hline Fungi & 51 taxa & $\begin{array}{l}\text { Suberkropp and Wallace (1992), Gulis and } \\
\text { Suberkropp (2004, 2003) }\end{array}$ \\
\hline Protista & $>7$ taxa & Vila (1996), Vila (personal communication) \\
\hline Nematoda & $>10$ taxa & Vila (1996), Vila (personal communication) \\
\hline Copepoda & 5 species & Vila (1996), Vila (personal communication) \\
\hline Cladocera & 1 species & Vila (1996), Vila (personal communication) \\
\hline Decapoda & 1 species & Wallace et al. (personal observations) \\
\hline Ostracoda & 1 species & Vila (1996), Vila (personal communication) \\
\hline Gastrotrichia & $>5$ taxa & Vila (1996), Vila (personal communication) \\
\hline Oligochaeta & $>4$ taxa & Vila (1996), Vila (personal communication) \\
\hline Branchiobdellida & 1 species & Wallace et al. (personal observations) \\
\hline Rotifera & $>10$ taxa & Vila (1996), Vila (personal communication) \\
\hline Turbellaria & $>4$ taxa & Vila (1996), Vila (personal communication) \\
\hline Tardigrada & 2 taxa & Vila (1996), Vila (personal communication) \\
\hline Acarina & $>3$ taxa & Vila (1996), Vila (personal communication) \\
\hline Bivalvia & 1 species & Wallace et al. (personal observations) \\
\hline Ephemeroptera & 4 families; 7 genera; $>7$ species & $\begin{array}{l}\text { Wallace } \text { et al. (personal observations), } \\
\text { Wallace } \text { et al. (1991), Lugthart and } \\
\text { Wallace (1992), Wallace } \text { et al. (1999) }\end{array}$ \\
\hline Odonata & 2 families; 2 genera; $>2$ species & $\begin{array}{l}\text { Wallace et al. (personal observations), } \\
\text { Wallace } \text { et al. (1991), Lugthart and } \\
\text { Wallace (1992), Wallace } \text { et al. (1999) }\end{array}$ \\
\hline Plecoptera & 6 families; 8 genera; $>8$ species & $\begin{array}{l}\text { Wallace } \text { et al. (personal observations), } \\
\text { Wallace et al. (1991), Lugthart and } \\
\text { Wallace (1992), Wallace } \text { et al. (1999) }\end{array}$ \\
\hline Coleoptera & 3 families; 4 genera; $>4$ species & $\begin{array}{l}\text { Wallace et al. (personal observations), } \\
\text { Wallace } \text { et al. (1991), Lugthart and } \\
\text { Wallace (1992), Wallace et al. (1999) }\end{array}$ \\
\hline Trichoptera & 14 families; 19 genera; $>20$ species & $\begin{array}{l}\text { Wallace } \text { et al. (personal observations), } \\
\text { Wallace } \text { et al.(1991), Lugthart and } \\
\text { Wallace (1992), Wallace } \text { et al. (1999) }\end{array}$ \\
\hline $\begin{array}{l}\text { Diptera } \\
\text { (incl. chironomids) }\end{array}$ & 15 families; 55 genera; $>59$ species & $\begin{array}{l}\text { Wallace et al. (personal observations), } \\
\text { Wallace et al. (1991), Lugthart and } \\
\text { Wallace (1992), Wallace } \text { et al. (1999), } \\
\text { Courtney }(1994,2000)\end{array}$ \\
\hline Hemiptera & 2 genera; 2 species & Wallace et al. (personal observations) \\
\hline Collembola & 1 family; 1 genus; $>1$ species & Wallace et al. (personal observations) \\
\hline Arachnida & 19 genera* & Sanzone (2001) \\
\hline Amphibia & 2 genera; 5 species & Johnson $(2001)$ \\
\hline Reptilia & $>3$ species & Wallace et al. (personal observations) \\
\hline Aves & 2 species & Wallace et al. (personal observations) \\
\hline Mammals & 4 species & Wallace et al. (personal observations) \\
\hline TOTAL & $>293$ taxa & \\
\hline
\end{tabular}

*Estimated from data on a site $\sim 2 \mathrm{~km}$ downstream.

Several bat species forage along streams for emerging insects and drink from the stream (Seidman and Zabel, 2001). Seven bat species in the genera Myotus, Corynorhinus, Lasionycteris and Eptesicus were observed feeding along intermittent streams in California (Seidman and Zabel, 2001). Bat activity was the greatest along the widest intermittent streams, but higher at all stream sizes than at upland sites.

Small mammals found in headwater stream habitats include shrews, voles, and moles. NatureServe (accessed July 2005) lists 5 species of shrews in the genus Sorex that are found in and on the banks of headwater streams in the USA. The star-nosed mole (Condylura cristata) digs tunnels that lead to small streams and is considered imperiled in the southeastern United States (Harvey and Clark, 1997). Mammals characteristic of small streams in the Pacific Northwest include Sorex bendirii, S. palustris, $S$. pacificus, Microtus richardsoni and M. longicau$d u s$; some are obligate headwater species whereas 
others are widespread but more abundant in headwaters (Richardson et al., 2005). Headwaters are also frequented by species such as raccoon, mink, beaver and otter, which may use them out of proportion to their areal extent on the landscape (Kruuk et al., 1998).

\section{Estimating Biological Diversity in a Headwater}

\section{Stream}

A complete species list does not exist for any headwater stream in the USA. However, based on the studies discussed here, a complete list would likely number in the hundreds to thousands of species. The invertebrate fauna of a first-order German stream (Breitenbach) has been investigated for many years. This $1-\mathrm{m}$-wide stream is home to 1004 invertebrate taxa (Allan, 1995). Many of these species are small invertebrates living in the hyporheic zone with connections to the ground water. Similar invertebrate diversity is likely to be found in the USA headwater streams. As an example, we consider three first-order, fishless streams (catchments $5-7.5$ ha in area and mean discharge $<2.5 \mathrm{l} / \mathrm{s}$ ) in the southern Appalachian Mountains of North Carolina, which are sites of ongoing long-term ecological research. These heavily shaded streams are in forested catchments and have a dense rhododendron riparian canopy. A list of known diversity in the taxonomic groups found associated with these three small streams is presented in Table 6. The groups about which we know the least (noninsect invertebrates) in these Appalachian streams are very diverse (400 taxa) in the Breitenbach, a small stream where they have been intensely studied (Allan, 1995). It is therefore likely that noninsect invertebrate diversity in the Appalachian streams is considerably higher than what we report here. Birds and reptiles associated with these streams have not been studied, so their diversity is unknown. Thus, we know that at least 293 taxa are associated with these three first-order streams, but their true diversity is likely at least twice that.

Headwater diversity is underestimated not only because of limited sampling, but also because so many headwater species remain undescribed. For example, half of the stonefly species associated with headwaters were described only in the last two to three decades (Stout and Wallace, 2003); new species of hydrobiid snails are continually being described; and a recent survey of ravine streams in the Florida panhandle found a dozen caddisfly species new to science (Rasmussen, 2004). Thorough surveys of small streams routinely discover new species, genera, and even families of invertebrates (Strayer, 2000). This is especially true for the hyporheic fauna living within the streambed, a habitat that is rarely sampled systematically.

\section{THE BIOLOGICAL IMPORTANCE OF SMALL STREAMS IN RIVER NETWORKS}

Headwater streams and springs may be small in size, but they provide habitats for a rich array of species, which enhances the biological diversity of the entire river system. Furthermore, the strong biological linkages between these upstream habitats and downstream ecosystems enhance and maintain species diversity downstream. The attributes of headwaters that make them essential habitats and that lead to linkages with other ecosystems are diagrammed in Figure 2 and discussed in this section.

\section{Headwaters Support Many Species That Occur Nowhere Else in the River System}

The previous sections provided numerous examples of species found only in headwaters. These species enhance diversity in the entire system (e.g., Paller, 1994). There are many reasons why headwater streams have a unique complement of species; we describe several here.

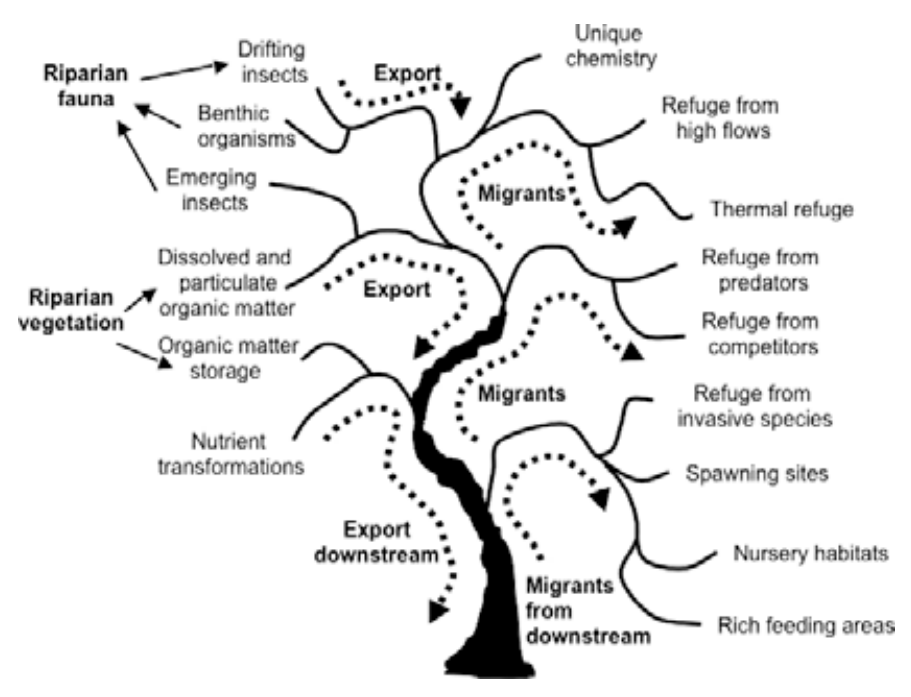

FIGURE 2. Factors That Contribute to the Biological Importance of Headwater Streams in River Networks. Attributes on the right benefit species unique to headwaters and also make headwaters essential seasonal habitats for migrants from downstream. On the left are biological contributions of headwater ecosystems to riparian and downstream ecosystems. 


\section{Headwaters Provide Unique and Highly} Diverse Physico-chemical Habitats. Headwater streams contribute to species richness in river systems in many ways, chief among which is the diverse array of unique habitats that they provide. As noted by a fish ecologist, "overall, there are probably more environmental, biological and ichthyological differences among different kinds of first-order streams than among stream reaches in higher orders" (Matthews, 1998; p. 311). Headwaters range from steep, swift, and cold mountain streams to warm, low-gradient, swampy tributaries. The light regime in small streams ranges from well lit to heavily shaded. Their chemistry reflects the catchment's soil, geology, and human disturbance regime (e.g., Williams et al., 1997). Their biology reflects the complement of species (both native and introduced) in the region and the presence or absence of barriers to exchange with neighboring ecosystems (e.g., downstream, riparian, or in adjacent valleys). The flow regime in small streams can be fairly constant in ground-water-fed springs, predictably variable from seasonal snow melt, intermittent with isolated pools sustained by ground-water connections, perennial with a flashy hydrograph after rainstorms, or one of many other variations. Small streams can serve as a refuge for species that are vulnerable to being swept downstream. With lower discharge and proximity to refuges from the current, small streams and springs offer a more benign habitat for species unable to maintain position in a strong current (e.g., Glazier, 1991; Dieterich and Anderson, 2000).

\section{Headwaters Provide a Refuge from Predators.}

The high vulnerability of amphipods to fish predation are considered to be one reason why amphipods reach such high abundance in small fishless springs (Glazier, 1991). Low numbers of predators in intermittent streams is considered to contribute to the high diversity of aquatic insects (Dieterich and Anderson, 2000), the high biomass of emerging insects (Progar and Moldenke, 2002), and crayfish abundance patterns (Flinders and Magoulick, 2003) in those streams. The absence of fish predators in high-elevation Colorado streams results in emerging female mayflies that are larger and more fecund (Peckarsky et al., 2002). The flight of adult stoneflies prior to oviposition is predominantly upstream for distances up to $730 \mathrm{~m}$ in a New Hampshire stream network; researchers speculate that this is because of the lower interspecific competition, lower predation risk, and higher food resources in the headwater tributaries (Macneale et al., 2005). The absence of fish predation is considered a factor responsible for the prevalence of salamanders and other amphibians in small streams (Petranka, 1998). The significance of predator-free environments for amphibians is apparent from the lower populations observed in stream networks where trout have been introduced into high mountain lakes (Pilliod and Peterson, 2001).

\section{Headwaters Provide a Refuge from} Competitors. Low abundance of competitively dominant species is another explanatory factor for the abundance and diversity of headwater species. The absence of dominant competitors such as the snail Juga silicula was considered a factor contributing to the diversity of grazing insects in western intermittent streams (Dieterich and Anderson, 2000). Interannual variation in abundance of native rainbow trout in an intermittent California stream was correlated with the intensity of winter floods, which destroy the eggs of introduced brook trout (Salvelinus fontinalis). This leaves fewer brook trout to compete with rainbow trout fry that hatch during the following spring (Erman and Hawthorne, 1976). The brook trout fry are competitive dominants in this stream because they are larger and more aggressive than rainbow trout fry (Erman and Hawthorne, 1976).

Headwaters Provide a Refuge from Alien Species. In the southern Appalachians, populations of native brook trout have been greatly reduced or displaced by the introduced rainbow trout throughout much of the stream network; brook trout persist in small, high-gradient headwater streams (Larson and Moore, 1985; Larson et al., 1995). Headwater pools in a Colorado stream provided habitats for Arkansas darters that were otherwise subjected to predation by an introduced pike (Labbe and Fausch, 2000). Headwater streams are recognized as the refuges for species that have been extirpated downstream and have been identified as the priority targets for freshwater conservation efforts (Saunders et al., 2002).

\section{Headwaters Are Essential for Species Living in Lar- ger Streams}

Genetic Linkages. Populations in headwaters are genetically connected to populations living in larger streams, and the genetic structure of stream populations provides a measure of this linkage. Little genetic differentiation from headwaters to downstream reaches was observed for distances up to $2.5 \mathrm{~km}$ in a stonefly population (Schultheis et al., 2002 ), up to $10 \mathrm{~km}$ in populations of a mayfly (Monaghan et al., 2001), and up to $20 \mathrm{~km}$ in a caddisfly population (Wilcock et al., 2003). This mixing of up- and downstream populations is a result of both larval and adult dispersal and illustrates the scale of biological linkages in river networks. 
Species Migrate to Headwaters for Spawning and Nursery Habitats. Small streams serve as vital spawning habitats for species that live in larger streams during most of the year. In addition to the many salmonids that spawn in small streams as discussed earlier, several darters (e.g., Etheostoma boschungi, E. trisella) migrate to small streams $(<1 \mathrm{~m}$ wide) for breeding (Ryon, 1986; Boschung and Mayden, 2004). Many lake-dwelling fish species also migrate to small tributaries for spawning. Examples include kokanee salmon (Oncorhynchus nerka, nonanadromous sockeye) and several species of California sucker, including the federally endangered shortnose and Lost River suckers (Chamistes brevirostris and Deltistes luxatus) (Moyle, 2002). Headwater streams provide a vital rearing habitat for the young of the many species that spawn there. Many of these species support important fisheries and are likely to suffer declines without access to intact headwaters even if the downstream habitats remain intact. Headwaters serve as spawning and nursery grounds for many of the reasons detailed above, namely that they offer a refuge from high flow, competitors, and predators.

\section{Headwaters Provide Rich Feeding Grounds.} Small streams are often areas of concentrated food resources for both permanent residents and migrants. Large inputs of leaves from forested riparian zones, the high retention capacity of small streams, and the high rates of primary productivity in unshaded headwaters mean that these streams are rich in food for primary consumers such as crustaceans and insects. Those organisms are eaten by resident and migrant invertebrate and vertebrate predators, and the large hatches of aquatic insects are important to aerial and terrestrial predators. Small streams also receive considerable input of terrestrial insects; e.g., terrestrial invertebrates were a more important food resource for fishes in a first and second-order stream than a third-order stream (Lotrich, 1973).

Headwaters Provide Thermal Refuges. Small streams offer a thermal refuge for species that spend most of their lives in larger systems. They provide warm refuges from freezing for stream fishes during winter (e.g., Power et al., 1999) and cool refuges during summer (e.g., Curry et al., 1997). The Arkansas darter, Etheostoma cragini, uses small first-order streams as a summer refuge from heat and drought in the Ozarks (Radwell, 2001). Arkansas darter populations are also found in intermittent streams in Colorado, where their persistence in temporarily isolated pools depends upon a supply of cool groundwater (Labbe and Fausch, 2000). Brook trout in the Ford River, Michigan, retreat to cooler headwaters in summer (Hayes et al., 1998). The success of quillback and introduced carp in midwestern streams has been attributed to the warming of small streams because of human disturbance of the landscape; native species in decline in this region require cooler tributaries (Karr et al., 1985). If headwater streams are thermally degraded, or if barriers to movement are established, downstream species lose access to these thermal refuges.

\section{Headwaters Provide a Source of Colonists and} a Network of Movement Corridors. Biological connectivity between headwater and downstream ecosystems is considerable and essential for the maintenance of species diversity in downstream ecosystems (e.g., Labbe and Fausch, 2000). One way in which small streams maintain diversity in the river network is by providing a source of colonists for recovery of downstream systems following disturbance (Lorion et al., 2000; Progar and Moldenke, 2002; Huryn et al., 2005). Small streams also provide movement corridors for plants and animals across the landscape. Their riparian zones provide cooler and more mesic conditions than those found in the uplands (e.g., Richardson et al., 2005). The flight paths of adult aquatic insects are concentrated along streams and riparian zones, which serve as dispersal corridors (e.g., Petersen et al., 2004).

\section{Headwater Biodiversity Affects the Character and Function of Terrestrial and Downstream Ecosystems}

Headwaters Supply Food to Neighboring Ecosystems. The diversity of organisms in headwaters creates food resources for other ecosystems and thus provides another ecological linkage between headwater and neighboring ecosystems: "headwater streams are the vertex of a network of trophic arteries flowing from the forest upland to the oceans" (Progar and Moldenke, 2002). Leaf-shredding insects commonly dominate the aquatic insect fauna in forested headwaters, and the fine particles of organic matter that shredders generate are exported as seston to support foodwebs of ecosystems downstream (Vannote et al., 1980). Elimination of aquatic insects from a headwater stream resulted in a $67 \%$ reduction in seston export to downstream ecosystems, which was a greater reduction than was caused by a severe drought (Cuffney et al., 1990). Sufficient numbers of drifting aquatic insects and detritus are exported from fishless headwater tributaries to support 1002,000 young-of-the-year salmonids per kilometer of larger salmon-bearing streams in Alaska (Wipfli and Gregovich, 2002). Emerging insects and transforming amphibians supply food for terrestrial organisms such as spiders, birds, and bats that forage in the 
riparian zone of small streams (e.g., Richardson et al., 2005). These nutrient and organic matter linkages support riparian and downstream ecosystems. Their significance has been discussed in greater detail elsewhere (Meyer and Wallace, 2001; Freeman et al., this issue; Wipfli et al., this issue).

\section{Biological Activity in Headwaters Affects} Connections to Neighboring Ecosystems. Small streams are sites of intense biological activity, whose consequences influence ecosystems downstream. For example, uptake of DOC in headwaters alters the quality and quantity of DOC exported to downstream ecosystems (Wiegner et al., 2005). Uptake of nutrients in headwaters alters nitrogen and phosphorus loading to ecosystems downstream (Meyer and Wallace, 2001; Alexander et al., this issue; Triska et al., this issue).

\section{THREATS TO SMALL STREAMS}

Despite their unique contributions to and importance in maintaining the diversity and functional integrity of entire river systems, small streams are continually under threat by human activity (Meyer and Wallace, 2001). The literature describing the biota of headwaters is replete with examples of species threatened by any number of human activities. Threats include ground-water extraction which, in addition to threatening species associated with small springs (e.g., Hubbs, 1995), has caused tributaries of Kansas streams to go dry, resulting in the extirpation of 16 species from the river system (Cross and Moss, 1987). Land-disturbing activities such as agriculture, logging, mining, and urbanization degrade and eliminate headwater habitats (Meyer and Wallace, 2001). These inconspicuous, unnamed, unmapped, and undocumented ecosystems, many of which are on private property, are thus extremely vulnerable to human impacts. The cumulative impact of degraded headwaters contributes to the loss of ecological integrity in ecosystems downstream.

Small streams are thus a vital part of the biological integrity of our nation's waterways. Degradation of headwater habitats and loss of their connections to larger streams have negative consequences not only for inhabitants of small streams but also for the diversity of downstream and riparian ecosystems. In many respects and locales, the biological integrity of entire river networks may be greatly dependent on the individual and cumulative impacts occurring in the many small streams that constitute their headwaters.

\section{ACKNOWLEDGMENTS}

We thank Keller Suberkropp, Rex Lowe, Jennifer Greenwood, Peter Vila, John Morse, Theresa Thom, Elizabeth McGee, and Winsor Lowe for providing information on particular taxonomic groups. Ben Stout was generous in allowing us to use his data. We thank Larry Master for a very helpful search of the NatureServe database. Our research on headwater streams in the southern Appalachians has been supported by NSF grants over three decades including DEB-0212315. The Meyerfauna lab group and three anonymous reviewers provided helpful comments on an earlier version of this paper. We thank Tracie Nadeau and Mark Rains for organizing this special issue and stimulating us to explore the extensive literature on headwater biodiversity.

\section{LITERATURE CITED}

Alexander, R.B., E.W. Boyer, R.A. Smith, G.E. Schwartz, and R.B. Moore, 2007. The Role of Headwater Streams in Downstream Water Quality. Journal of the American Water Resources Association 43, DOI: 10.1111/j.1752-1688.2007.00005.x.

Allan, J.D, 1995. Stream Ecology. Kluwer Academic Publishers, Boston, Massachussets.

Anderson, T.M., and N.H. Anderson, 1995. The Insect Fauna of Spring Habitats in Semiarid Rangelands in Central Oregon. Journal of the Kansas Entomological Society 68(Suppl. 2):65-76.

Balsamo, M., and M.A. Todaro, 2002. Gastrotricha. In: Freshwater Meiofauna: Biology and Ecology, S.D. Rundle, A.L. Robertson, and J.M. Schmid-Araya (Editors). Backhuys Publishers, Leiden, pp. 45-61.

Bärlocher, F., and M.A.S. Graca, 2002. Exotic Riparian Vegetation Lowers Fungal Diversity but not Leaf Decomposition in Portuguese Streams. Freshwater Biology 47:1123-1135.

Baattrup-Pederson, A., S.E. Larsen, and T. Riis, 2003. Composition and Richness of Macrophyte Communitites in Small Danish Streams - Influence of Environmental Factors and Weed Cutting. Hydrobiologia 495:171-179.

Biggs, B.J, 1996. Patterns in Benthic Algae of Streams. In: Algal Ecology, R.J. Stevenson, M.L. Bothwell, and R.L. Lowe (Editors). Academic Press, New York, pp. 31-56.

Blackwood, M.A., S.M. Hall, and L.C. Ferrington Jr, 1995. Emergence of Chironomidae from Springs in the Central High Plains Region of the United States. Journal of the Kansas Entomological Society 68(Suppl. 2):132-151.

Boschung, H.T. Jr, and R.L. Mayden, 2004. Fishes of Alabama. Smithsonian Press, Washington, District of Columbia.

Brown, T.G., and G.F. Hartman, 1988. Contribution of Seasonally Flooded Lands and Minor Tributaries to the Production of Coho Salmon in Carnation Creek, British Columbia. Transactions of the American Fisheries Society 117:546-551.

Bub, B.R., D.J. Flaspohler, and C.J.F. Huckins, 2004. Riparian and Upland Breeding-bird Assemblages Along Headwater Streams in Michigan's Upper Peninsula. Journal of Wildlife Management 68:383-392.

Buhlmann, K.A., and J.W. Gibbons, 1997. Imperiled Aquatic Reptiles of the Southeastern United States: Historical Review and Current Conservation Status. In: Aquatic Fauna in Peril: The Southeastern Perspective, G.W. Benz, and D.E. Collins (Editors). Southeast Aquatic Research Institute Special Publication 1. Lenz Design and Communications, Decatur, GA, pp. 201-232.

Burkhead, N.M., and H.L. Jelks, 2000. Diversity, Levels of Impairment, and Cryptic Fishes in the Southeastern United States. In: Freshwater Ecoregions of North America: A Conservation Assessment, R.A. Abell, D.M. Olson, E. Dinerstein, et al. (Editors). Island Press, Washington, pp. 30-32. 
Burkhead, N.M., S.J. Walsh, B.J. Freeman, and J.D. Williams, 1997. Status and Restoration of the Etowah River: An Imperiled Southern Appalachian Ecosystem. In: Aquatic Fauna in Peril: The Southeastern Perspective, G.W. Benz, and D.E. Collins (Editors). Southeast Aquatic Research Institute Special Publication 1. Lenz Design and Communications, Decatur, Georgia, pp. $375-444$.

Burton, T.M., and G.E. Likens, 1975. Energy Flow and Nutrient Cycling in Salamander Populations in the Hubbard Brook Experimental Forest. Ecology 56:1068-1080.

Courtney, G.W, 1994. Biosystematics of the Nymphomyiidae (Insecta: Diptera): Life History, Morphology, and Phylogenetic Relationships. Smithsonian Contributions to Zoology, Number 550. Smithsonian Institution Press, Washington, District of Columbia.

Courtney, G.W, 2000. Revision of the Net-Winged Midges of the Genus Blepharicera Macquart (Diptera: Blephariceridae) of Eastern North America. Memoirs of the Entomological Society of Washington, Number 23. The Entomological Society of Washington, Washington, District of Columbia.

Covich, A.P., and J.H. Thorp, 1991. Crustacea: Introduction and Peracarida. In: Ecology and Classification of North American Freshwater Invertebrates, J.H. Thorp, and A.P. Covich (Editors). Academic Press, San Diego, California, pp. 665-689.

Cross, F.B., and R.E. Moss, 1987. Historic Changes in Fish Communities and Aquatic Habitats in Plains Streams of Kansas. In: Community and Evolutionary Ecology of North American Stream Fishes, W.J. Matthews, and D.C. Heins (Editors). University of Oklahoma Press, Norman, Oklahoma, pp. 155-165.

Cuffney, T.F., J.B. Wallace, and G.J. Lugthart, 1990. Experimental Evidence Quantifying the Role of Benthic Invertebrates in Organic Matter Dynamics of Headwater Streams. Freshwater Biology 23:281-299.

Curry, R.A., C. Brady, D.L.G. Noakes, and R.G. Danzmann, 1997. Use of Small Streams by Young Brook Trout Spawned in a Lake. Transactions of the American Fisheries Society 126:77-83.

Delong, M.D, 2005. Upper Mississippi River Basin. In: Rivers of North America, A.C. Benke, and C.E. Cushing (Editors). Elsevier, New York, pp. 327-374.

Di Sabatino, A., P. Martin, R. Gerecke, and B. Cirolani, 2002. Hydrachnida (Water Mites). In: Freshwater Meiofauna: Biology and Ecology, S.D. Rundle, A.L. Robertson, and J.M. SchmidAraya (Editors). Backhuys Publishers, Leiden, pp. 105-133.

Di Sabatino, A., B. Cicolani, and R. Gerecke, 2003. Biodiversity and Distribution of Water Mites (Acari, Hydrachnidia) in Spring Habitats. Freshwater Biology 48:2163-2173.

Dieterich, M., and N.H. Anderson, 2000. The Invertebrate Fauna of Summer-Dry Streams in Western Oregon. Archiv für Hydrobiologie 147:273-295.

Erman, N.A., and D.C. Erman, 1995. Spring Permanence, Trichoptera Species Richness, and the Role of Drought. Journal of the Kansas Entomological Society 68:50-64.

Erman, D.C., and V.M. Hawthorne, 1976. The Quantitative Importance of an Intermittent Stream in the Spawning of Rainbow Trout. Transactions of the American Fisheries Society 105:675681.

Etnier, D.A, 1997. Jeopardized Southeastern Freshwater Fishes: A Search for Causes. In: Aquatic Fauna in Peril: The Southeastern Perspective, G.W. Benz, and D.E. Collins (Editors). Southeast Aquatic Research Institute Special Publication 1. Lenz Design and Communications, Decatur, pp. 87-104.

Evans, J.W., and R.L. Noble, 1979. The Longitudinal Distribution of Fishes in an East Texas Stream. American Midland Naturalist 101:333-343.

Fausch, K.D., and R.G. Bramblett, 1991. Disturbance and Fish Communities in Intermittent Tributaries of a Western Great Plains River. Copeia 1991:659-674.
Fauth, J.E. and W.J. Resetarits Jr, 1991. Interactions Between the Salamander Siren intermedia and the Keystone Predator Notophthalmus viridescens. Ecology 72:827-838.

Feminella, J.W, 1996. Comparison of Benthic Macroinvertebrate Assemblages in Small Streams Along a Gradient of Flow Permanence. Journal of the North American Benthological Society 15:651-669.

Fend, S.V., and R.O. Brinkhurst, 2000. New Species of Rhynchelmis (Clitellata, Lumbriculidae), with Observations on the Nearctic Species. Hydrobiologia 428:1-59.

Fend, S.V., and D.L. Gustafson, 2001. A New Lumbriculid Genus and Species from North America (Clitellata, Lumbriculidae). Hydrobiologia 463:13-22.

Flinders, C.A., and D.D. Magoulick, 2003. Effects of Habitat Permanence on Crayfish Community Structure. American Midland Naturalist 149:134-147.

Freeman, M.C., C.M. Pringle, and C.R. Jackson, 2007. Hydrologic Connectivity and the Contribution of Stream Headwaters to Ecological Integrity at Regional and Global Scales. Journal of the American Water Resources Association 43, DOI: 10.1111/ j.1752-1688.2007.00002.x.

Frest, T.J., and E.J. Johannes, 1999. Field Guide to Survey and Manage Freshwater Mollusk Species. BLM/OR/WA/PL99/045+1792. http://www.or.blm.gov/surveyandmanage.html, accessed July 2005.

Galassi, D., P. Marmonier, M.-J. Dole-Olivier, and S. Rundle, 2002. Microcrustacea. In: Freshwater Meiofauna: Biology and Ecology, S.D. Rundle, A.L. Robertson, and J.M. Schmid-Araya (Editors). Backhuys Publishers, Leiden, pp. 135-175.

Glazier, D.S, 1991. The Fauna of North American Temperate Cold Springs: Patterns and Hypotheses. Freshwater Biology 26:527542.

Glime, J.M, 1968. Ecological Observations on Some Bryophytes in Appalachian Mountain Streams. Castanea 33:300-325.

Gray, L.J, 1993. Response of Insectivorous Birds to Emerging Aquatic Insects in Riparian Habitats of a Tallgrass Prairie Stream. American Midland Naturalist 129:288-300.

Greenwood, J.L, 2004. The Response of Detrital and Autotrophic Resources to Long-Term Nutrient Enrichment in a Detritusbased Headwater Stream. Ph.D. Dissertation, University of Georgia, Athens, Georgia, 167 pp.

Greenwood, J.L., and A.D. Rosemond, 2005. Periphyton Response to Long-term Nutrient Enrichment in a Shaded Headwater Stream. Canadian Journal of Fisheries and Aquatic Sciences 62:2033-2045

Gulis, V., and K. Suberkropp, 2003. The Effect of Excluding Plant Litter on the Aquatic Hyphomycete Conidia in a Headwater Stream. Czech Mycology 54:249-260.

Gulis, V., and K. Suberkropp, 2004. Effects of Whole-Stream Nutrient Enrichment on the Concentration and Abundance of Aquatic Hypohomycete Conidia in Transport. Mycologia 96:57-65.

Gurtz, M.E, 1981. Ecology of Stream Invertebrates in a Forested and a Commercially Clear-Cut Watershed. Ph.D. Dissertation, University of Georgia, Athens, Georgia.

Haggerty, S.M., D.P. Batzer, and C.R. Jackson, 2002. Macroinvertebrate Assemblages in Perennial Headwater Streams of the Coastal Mountain range of Washington, USA. Hydrobiologia 479:143-154.

Hall, R.O. Jr, and J.L. Meyer, 1998. The Trophic Significance of Bacteria in a Detritus-Based Stream Food Web. Ecology 79:1995-2012.

Harvey, M.J., and J.D. Clark, 1997. Imperiled Mammalian Fauna of Aquatic Ecosystems in the Southeast: A Historical Perspective. In: Aquatic Fauna in Peril: The Southeastern Perspective, G.W. Benz, and D.E. Collins (Editors). Southeast Aquatic Research Institute Special Publication 1. Lenz Design and Communications, Decatur, Georgia, pp. 245-258. 
Hayes, D.B., W.W. Taylor, M.T. Drake, S.M. Marod, and G.E. Whelan, 1998. The Value of Headwaters to Brook Trout (Salvelinus fontinalis) in the Ford River, Michigan, USA. In: Headwaters: Water Resources and Soil Conservation, M.J. Haigh, J. Krecek, G.S. Rajwar, and M.P. Kilmartin (Editors). A.A. Balkema, Rotterdam, Netherlands, pp. 175-185.

Heino, J, R. Paavola, R. Virtanen, and T. Muotka, 2005. Searching for Biodiversity Indicators in Running Waters: Do Bryophytes, Macroinvertebrates and Fish Show Congruent Diversity Patterns Biodiversity and Conservation 14:415-428.

Herschler, R, 1994. A Review of the North American Freshwater Snail Genus Pyrgulopsis (Hydrobiidae). Smithsonian Contributions to Zoology 554:1-115.

Horvath, T, 2004. Retention of Particulate Matter by Macrophytes in a First-Order Stream. Aquatic Botany 78:27-36.

Hubbs, C, 1995. Springs and Spring Runs as Unique Aquatic Systems. Copeia 1995(4):989-991.

Huryn, A.D, 1990. Growth and Voltinism of Lotic Midge Larvae: Patterns Across an Appalachian Mountain Basin. Limnology and Oceanography 35:339-351.

Huryn, A.D., and J.B. Wallace, 1985. Life History and Production of Goerita semata Ross (Trichoptera: Limnephilidae) in the Southern Appalachian Mountains. Canadian Journal of Zoology 63:2604-2611.

Huryn, A.D., and J.B. Wallace, 1987a. Local Geomorphology as a Determinant of Macrofaunal Production in a Mountain Stream. Ecology 68:1932-1942.

Huryn, A.D., and J.B. Wallace, 1987b. The Exopterygote Insect Community of a Mountain Stream in North Carolina, USA: Life Histories, Production, and Functional Structure. Aquatic Insects 4:229-251.

Huryn, A.D., and J.B. Wallace, 1988. Community Structure of Trichoptera in a Mountain Stream: Spatial Patterns of Production and Functional Organization. Freshwater Biology 20:141155.

Huryn, A.D., K.A. Slavik, R.L. Lowe, S.M. Parker, D.S. Anderson, and B.J. Peterson, 2005. Landscape Heterogeneity and the Biodiversity of Arctic Stream Communities: A Habitat Template Analysis. Canadian Journal of Fisheries and Aquatic Sciences 62:1905-1919.

Irons, J.G., L.K. Miller, and M.W. Oswood, 1993. Ecological Adaptations of Aquatic Macroinvertebrtes to Overwintering in Interior Alaska (US) Sub-Arctic Streams. Canadian Journal of Zoology 71:98-108.

Jacobi, G.Z., and S.J. Cary, 1996. Winter Stonefilies (Plecoptera) in Seasonal Habitats in New Mexico, USA. Journal of the North American Benthological Society 15:690-699.

Johnson, B.R, 2001. Effects of Resource Manipulation on Selected Primary and Secondary Consumers in Two Detritus-Based Southern Appalachian Streams. Ph.D. Dissertation, University of Georgia, Athens, Georgia.

Johnson, P.D., and K.M. Brown, 2000. The Importance of Microhabitat Factors and Habitat Stability to the Threatened Louisiana Pearl Shell, Margaritifera hembeli (Conrad). Canadian Journal of Zoology 78:271-277.

Johnson, B.R., and J.B. Wallace, 2005. Bottom-Up Limitation of a Stream Salamander in a Detritus-Based Food Web. Canadian Journal of Fisheries and Aquatic Sciences 62:301-311.

Karr, J.R., L.A. Toth, and D.R. Dudley, 1985. Fish Communities of Midwestern Rivers: A History of Degradation. BioScience 35(2):90-95.

Koetsier, P. III, J.V. McArthur, and L.G. Leff, 1997. Spatial and Temporal Response of Stream Bacteria to Sources of Dissolved Organic Carbon in a Blackwater Stream System. Freshwater Biology 37:79-89.

Kolasa, J, 1983. Formation of the Turbellarian Fauna in a Submontane Stream. Acta Zoologica Cracoviensia 26:57-107.
Kolasa, J, 2002. Microturbellaria. In: Freshwater Meiofauna: Biology and Ecology, S.D. Rundle, A.L. Robertson, and J.M. Schmid-Araya (Editors). Backhuys Publishers, Leiden, pp. 1-14.

Kruuk, H., D.N. Carss, J.W.H. Conroy, and M.J. Gaywood, 1998. Habitat Use and Conservation of Otters (Lutra lutra) in Britain: A Review. In: Behaviour and Ecology of Riparian Mammals, N. Dunstone, and M.L. Gorman (Editors). Cambridge University Press, Cambridge, pp. 119-133.

Kuehne, R.A, 1962. A Classification of Streams, Illustrated by Fish Distribution in an Eastern Kentucky Creek. Ecology 43:608-614.

Labbe, T.R., and K.D. Fausch, 2000. Dynamics of Intermittent Stream Habitat Regulate Persistence of a Threatened Fish at Multiple Scales. Ecological Applications 10:1774-1791.

Lamberti, G.A, 1996. The Role of Periphyton in Benthic Food Webs. In: Algal Ecology, R.J. Stevenson, M.L. Bothwell, and R.L. Lowe (Editors). Academic Press, New York, pp. 533-572.

Larson, G.L., and S.E. Moore, 1985. Encroachment of Exotic Rainbow Trout into Stream Populations of Native Brook Trout in the Southern Appalachian Mountains. Transactions of the American Fisheries Society 114:195-203.

Larson, G.L., S.E. Moore, and B. Carter, 1995. Ebb and Flow of Enroachment by Nonnative Rainbow Trout in a Small Stream in the Southern Appalachian Mountains. Transactions of the American Fisheries Society 124:613-622.

Lorion, C.M., D.F. Markle, S.B. Reid, and M.E. Docker, 2000. Redescription of the Presumed-Extinct Miller Lake Lamprey, Lampetra minima. Copeia 2000:1019-1028.

Lotrich, V.A, 1973. Growth, Production, and Community Composition of Fishes Inhabiting a First-, Second-, and Third-Order Stream of Eastern Kentucky. Ecological Monographs 43:377397.

Lowe, W.H., and D.T. Bolger, 2002. Local and Landscape-Scale Predictors of Salamander Abundance in New Hampshire Headwater Streams. Conservation Biology 16:183-193.

Lugthart, G.J., and J.B. Wallace, 1992. Effects of Disturbance on Benthic Functional Structure and Production in Mountain Streams. Journal of the North American Benthological Society 11:138-164.

Macneale, K.H., B.L. Peckarsky, and G.E. Likens, 2005. Stable Isotopes Identify Dispersal Patterns of Stonefly Populations Living Along Stream Corridors. Freshwater Biology 50:1117-1130.

Matthews, W.J, 1998. Patterns in Freshwater Fish Ecology. Chapman and Hall, New York.

McArthur, J.V., L.G. Leff, and M.H. Smith, 1992. Genetic Diversity of Bacteria Along a Stream Continuum. Journal of the North American Benthological Society 11:269-272.

McCabe, D.J., and J.L. Sykora, 2000. Community Structure of Caddisflies Along a Temperate Springbrook. Archiv für Hydrobiologie 148:263-282.

McKey-Fender, D., and W.M. Fender, 1988. Phagodrilus gen. nov. (Lumbriculidae) - Systematics and Biology of a Predaceous Oligochaete from Western North America. Canadian Journal of Zoology 66:2304-2311.

Menhinick, E.F, 1991. The Freshwater Fishes of North Carolina. North Carolina Wildlife Resources Commission, Raleigh NC.

Meyer, J.L., and J.B. Wallace, 2001. Lost Linkages and Lotic Ecology: Rediscovering Small Streams. In: Ecology: Achievement and Challenge, M.C. Press, N.J. Huntly, and S. Levin (Editors). Blackwell Science, Malden, Massachusetts, pp. 295-317.

Monaghan, M.T., P. Spaak, C.T. Robinson, and J.V. Ward, 2001. Genetic Differentiation of Baetis alpinus Pictet (Ephemeroptera:Baetidae) in Fragmented Alpine Streams. Heredity 86:395403.

Morse, J.C., and C.B. Barr, 1990. Unusual Caddisfly (Trichoptera) Fauna of Schoolhouse Springs, Louisiana, with Description of a New Species of Diplectrona (Hydropsychidae). Proceedings of the Entomological Society of Washington 92:58-65. 
Morse, J.C., J.W. Chapin, D.D. Herlong, and R.S. Harvey, 1980. Aquatic Insects of Upper Three Runs Creek, Savannah River Plant, South Carolina. Part I: Orders Other than Diptera. Journal of the Georgia Entomological Society 15:69-101.

Morse, J.C., J.W. Chapin, D.D. Herlong, and R.S. Harvey, 1983. Aquatic Insects of Upper Three Runs Creek, Savannah River Plant, South Carlina. Part II. Diptera. Journal of the Georgia Entomological Society 18:300-316.

Morse, J.C., B.P. Stark, W.P. McCafferty, and K.J. Tennessen, 1997. Southern Appalachian and Other Southeastern Streams at Risk: Implications for Mayflies, Dragonflies and Damseflies, Stoneflies and Caddisflies. In: Aquatic Fauna in Peril: the Southeastern Perspective, G.W. Benz, and D.E. Collins (Editors). Southeastern Aquatic Research Institute, Special Publication 1. Lenz Design and Communications, Decatur, Georgia, pp. 17-42.

Moyle, P.B, 2002. Inland Fishes of California. University of California Press, Berkeley, California.

Moyle, P.B., and B. Herbold, 1987. Life-History Patterns and Community Structure in Stream Fishes of Western North America: Comparisons with Eastern North America and Europe. In: Community and Evolutionary Ecology of North American Stream Fishes, W.J. Matthews, and D.C. Heins (Editors). University of Oklahoma Press, Norman, Oklahoma, pp. 25-32.

Murray, N.L., and D.F. Stauffer, 1995. Nongame Bird Use of Habitat in Central Appalachian Riparian Forests. Journal of Wildlife Management 59:78-88.

NatureServe, 2003. http://www.natureserve.org, accessed July and October 2005.

Nelson, D.R., and S.J. McInnes, 2002. Tardigrada. In: Freshwater Meiofauna: Biology and Ecology, S.D. Rundle, A.L. Robertson, and J.M. Schmid-Araya (Editors). Backhuys Publishers, Leiden, pp. 177-215.

Paller, M.H, 1994. Relationships Between Fish Assemblage Structure and Stream Order in South Carolina Coastal Plain Streams. Transactions of the American Fisheries Society 123:150-161.

Peckarsky, B.L., A.R. McIntosh, B.W. Taylor, and J. Dahl, 2002. Predator Chemicals Induce Changes in Mayfly Life History Traits: A Whole-Stream Manipulation. Ecology 83:612-618.

Petersen, I., Z. Masters, A.G. Hildrew, and S.J. Ormerod, 2004. Dispersal of Adult Aquatic Insects in Catchments of Differing Land Use. Journal of Applied Ecology 41:934-950.

Petranka, J.W, 1998. Salamanders of the United States and Canada. Smithsonian Institution Press, Washington, District of Columbia.

Pilliod, D.S., and C.R. Peterson, 2001. Local and Landscape Effects of Introduced Trout on Amphibians in Historically Fishless Watersheds. Ecosystems 4:322-333.

Power, G., R.S. Brown, and J.G. Imhof, 1999. Groundwater and Fish - Insights from Northern North America. Hydrological Processes 13:401-422.

Progar, R.A., and A.R. Moldenke, 2002. Insect Production from Temporary and Perennially Flowing Headwater Streams in Western Oregon. Journal of Freshwater Ecology 17:391-407.

Prosser, D.J., and R.P. Brooks, 1998. A Verified Habitat Suitability Index for the Louisiana Waterthrush. Journal of Field Ornithology 69:288-298.

Radwell, A, 2001. Efforts to Protect Critical Fish Habitat Has Heuristic Value for Student Subunit. Fisheries 26:28.

Rasmussen, A.K, 2004. Species Diversity and Ecology of Trichoptera (Caddisflies) and Plecoptera (Stoneflies) in Ravine Ecosystems of Northern Florida. Ph.D. Dissertation, University of Florida, Gainesville, Florida, 130 p.

Richardson, J.S., R.J. Naiman, F.J. Swanson, and D.E. Hibbs, 2005. Riparian Communities Associated with Pacific Northwest Headwater Streams: Assemblages, Processes and Uniqueness. Journal of the American Water Resources Association 41(4):935-948.
Ryon, M.G, 1986. The Life History and Ecology of Etheostoma trisella (Pisces: Percidae). American Midland Naturalist 115:73-86.

Sanzone, D.M, 2001. Linking Communities Across Ecosystem Boundaries: The Influence of Aquatic Subsidies on Terrestrial Predators. Ph.D. Dissertation, University of Georgia, Athens, Georgia.

Saunders, D.L., J.J. Meeuwig, and A.C.J. Vincent, 2002. Freshwater Protected Areas: Strategies for Conservation. Conservation Biology 16:30-41.

Schlosser, I.J, 1987. A Conceptual Framework for Fish Communities in Small Warmwater Streams. In: Community and Evolutionary Ecology of North American Stream Fishes, W.J. Matthews, and D.C. Heins (Editors). University of Oklahoma Press, Norman, Oklahoma, pp. 17-32.

Schmid-Araya, J, 1998. Small-Sized Invertebrates in a Gravel Stream: Community Structure and Variability of Benthic Rotifers. Freshwater Biology 39:25-39.

Schultheis, A.S., L.A. Weigt, and A.C. Hendricks, 2002. Gene Flow, Dispersal, and Nested Clade Analysis Among Populations of the Stonefly Peltoperla tarteri in the Southern Appalachians. Molecular Ecology 11:317-327.

Schwank, P, 1981a. Turbellarien, Oligochaeten und Archianneliden des Breitenbachs und Anderer Oberheissischer Mittelgebirgsbäche. I. Lokalgeographische Verbrietung und die Verteilung der Arten in den Einzelnen Gewässern in Abhängigkeit vom Substrat. Archiv für Hydrobiologie Supplementband 62:1-85.

Schwank, P, 1981b. Turbellarien, Oligochaeten und Archianneliden des Breitenbachs und Anderer Oberheissischer Mittelgebirgsbäche. II. Die Systematik und Autökologie der Einzelnen Arten. Archiv für Hydrobiologie Supplementband 62:86-147.

Scott, M., and G.S. Helfman, 2001. Native Invasions, Homogenization, and the Mismeasure of Integrity of Fish Assemblages. Fisheries 26:6-15.

Seidman, V.M., and C.J. Zabel, 2001. Bat Activity Along Intermittent Streams in Northwestern California. Journal of Mammalogy 82:738-747.

Sherwood, A.R., T.L. Rintoul, K.M. Muller, and R.G. Sheath, 2000. Seasonality and Distribution of Epilithic Diatoms, Macroalgae and Macrophytes in a Spring-Fed Stream System in Ontario, Canada. Hydrobiologia 435:143-152.

Smiley, P.C. Jr, E.D. Dibble, and S.H. Schoenholtz, 2005. Fishes of First-Order Streams in North-Central Mississippi. Southeastern Naturalist 4(2):219-236.

Stebbins, R.C., and N.W. Cohen, 1995. A Natural History of Amphibians. Princeton University Press, Princeton, New Jersey.

Steinman, A.D, 1996. Effects of Grazers on Freshwater Benthic Algae. In: Algal Ecology: Freshwater Benthic Ecosystems, R.J. Stevenson, M.L. Bothwell, and R.L. Lowe (Editors). Academic Press, San Diego, California, pp. 341-373.

Stone, P.A, 2001. Movements and Demography of the Sonoran Mud Turtle, Kinosternon sonoriense. Southwestern Naturalist 46:4153.

Stout, B., and J.B. Wallace, 2003. A Survey of Eight Aquatic Insect Orders Associated with Small Headwater Streams Subject to Valley Fills from Mountaintop Mining. http://www.epa.gov/ region3/mtntop/pdf/Appendices/Appendix\%20D\%20Aquatic/ StoutWallaceMacroinvertebrate.pdf

Strayer, D.L, 2000. North America's Freshwater Invertebrates: A Research Priority. In: Freshwater Ecoregions of North America. A Conservation Assessment, R.A. Abell, D.M. Olson, E. Dinerstein, et al. (Editors). Island Press, Washington, District of Columbia, p. 104.

Strayer, D.L., and W.D. Hummon, 2001. Gastrotricha. In: Ecology and Classification of Freshwater Invertebrates of North America, (Second Edition), J.H. Thorp, and A.P. Covich (Editors). Academic Press, San Diego, California, pp. 181-194. 
Stream Bryophyte Group, 1999. Roles of Bryophytes in Stream Ecosystems. Journal of the North American Benthological Society 18:151-184.

Suberkropp, K., and J.B. Wallace, 1992. Aquatic Hyphomycetes in Insecticide-Treated and Untreated Streams. Journal of the North American Benthological Society 11:165-171.

Taylor, C.M., and M.L. Warren Jr., 2001. Dynamics in Species Composition of Stream Fish Assemblages: Environmental Variability and Nested Subsets. Ecology 82:2320-2330.

Taylor, C.A., M.L. Warren Jr, J.F. Fitzpatrick Jr, H.H. Hobbs III, R.F. Jezerinac, W.L. Pflieger, and H.W. Robison, 1996. Conservation Status of Crayfishes of the United States and Canada. Fisheries 21:25-38.

Tiedje, J.M., S. Brempong, K. Nusslein, T.L. Marsh, and S.J. Flynn, 1999. Opening the Black Box of Soil Microbial Diversity. Applied Soil Ecology 13:109-122.

Tramer, E.J, 1977. Catastrophic Mortality of Stream Fishes Trapped in Shrinking Pools. American Midland Naturalist 97:469-478.

Traunsperger, W, 2002. Nematoda. In: Freshwater meiofauna: Bio$\log y$ and Ecology, S.D. Rundle, A.L. Robertson, and J.M. Schmid-Araya (Editors). Backhuys Publishers, Leiden, pp. 63-104.

Triska, F.J., J.H. Duff, A.P. Jackman, R. Shibley, and R.J. Avanzino, 2007. Mississippi River Hypoxia: In the Beginning... Journal of the American Water Resources Association 43, DOI: 10.1111/j.1752-1688.2007.00006.x.

Tsui, C.K.M., K.D. Hyde, and I.J. Hotchkiss, 2001. Longitudinal and Temporal Distribution of Freshwater Ascomycetes and Dematiaceous Hyphomycetes on Submerged Wood in the Lam Tsuen River, Hong Kong. Journal of the North American Benthological Society 20:533-549.

Vannote, R.L., G.W. Minshall, K.W. Cummins, J.R. Sedell, and C.E. Cushing, 1980. The River Continuum Concept. Canadian Journal of Fisheries and Aquatic Sciences 37:130-137.

Vila, P.B, 1996. Size Structure of the Zoobenthos in Headwater Streams: Meiofaunal-Macroinvertebrate Interactions. Ph.D. Dissertation, University of Georgia, Athens, Georgia.

Wallace, R.L., and C. Ricci, 2002. Rotifera. In: Freshwater Meiofauna: Biology and Ecology, S.D. Rundle, A.L. Robertson and J.M. Schmid-Araya (Editors). Backhuys Publishers, Leiden, pp. 1544.

Wallace, J.B., A.D. Huryn, and G.J. Lugthart, 1991. Colonization of a Headwater Stream During Three Years of Seasonal Insecticidal Applications. Hydrobiologia 211:65-76.

Wallace, J.B., J.R. Webster, and R.L. Lowe, 1992. High-Gradient Streams of the Appalachians. In: Biodiversity of Southeastern United States Aquatic Communities, C.T. Hackney, S.M. Adams, and W.A. Martin (Editors) Wiley, New York, pp. 133-191.

Wallace, J.B., S.L. Eggert, J.L. Meyer, and J.R. Webster, 1999. Effects of Resource Limitation on a Detrital-Based Ecosystem. Ecological Monographs 69:409-442.

Warren, M.L., H.W. Robison, S.T. Ross, W.C. Starnes, B.M. Burr, S.J. Walsh, H.L. Bart, Jr., R.C. Cashner, D.A. Etnier, B.J. Freeman, B.R. Kuhajda and R.L. Mayden, 2000. Diversity, Distribution, and Conservation Status of the Native Freshwater Fishes of the Southern United States. Fisheries 25:7-31.

Weldon, C., L.H., du Preez, A.D. Hyatt, R. Muller, and R. Speare, , 2004. Origin of the Amphibian Chytrid Fungus. Emerging Infectious Diseases [serial on the Internet]. http://www.cdc.gov/ncidod/EID/vol10no12/03-0804.htm, accessed October 2005.

Werner, J.K., and M.B. McCune, 1979. Seasonal Changes in Anuran Populations in a Northern Michigan Pond. Journal of Herpetology 13:101-104.

Whiteside, B.G., and R.M. McNatt, 1972. Fish Species Diversity in Relation to Stream Order and Physicochemical Conditions in the Plum Creek Drainage Basin. American Midland Naturalist 88:90-101.
Wiebe, K.L., and K. Martin, 1998. Seasonal Use by Birds of Stream-Side Riparian Habitat in Coniferous Forest of Northcentral British Columbia. Ecography 21:124-134.

Wiegner, T.N., L.A. Kaplan, J.D. Newbold, and P.H. Ostrom, 2005. Contribution of Dissolved Organic C to Stream Metabolism: A Mesocosm Study Using ${ }^{13} \mathrm{C}$-enriched Tree-tissue Leachate. Journal of the North American Benthological Society 24:48-67.

Wigington, P.J., J.L. Ebersole, M.E. Colvin, S.G. Leibowitz, B. Miller, B. Hansen, H. Lavigne, D. White, J.P. Baker, M.R. Church, J.R. Brooks, M.A. Cairns, and J.E. Compton, 2006. Coho Salmon Dependence on Intermittent Streams. Frontiers in Ecology and the Environment 4:513-518.

Wilcock, H.R., R.A. Nichols, and A.G. Hildrew, 2003. Genetic Population Structure and Neighbourhood Population Size Estimates of the Caddisfly Plectrocnemia conspersa. Freshwater Biology 48:1813-1824.

Williams, D.D., N.E. Williams, and Y. Cao, 1997. Spatial Differences in Macroinvertebrate Community Structure in Springs in Southeastern Ontario in Relation to Their Chemical and Physical Environments. Canadian Journal of Zoology 75:1404-1414.

Wipfli, M.S., and D.P. Gregovich, 2002. Export of Invertebrates and Detritus from Fishless Headwater Streams in Southeastern Alaska: Implications for Downstream Salmonid Production. Freshwater Biology 47:957-969.

Wipfli, M.S., J.S. Richardson, and R.J. Naiman, 2007. Ecological Linkages Between Headwaters and Downstream Ecosystems: Transport of Organic Matter, Invertebrates, and Wood Down Headwater Channels. Journal of the American Water Resources Association 43, DOI: 10.1111/j.1752-1688.2007.00007.x. 